\title{
Geothermal investigations in western Anatolia using equilibrium temperatures from shallow boreholes
}

\author{
K. Erkan \\ Department of Civil Engineering, Marmara University, 34722, Göztepe, Istanbul, Turkey \\ Correspondence to: K. Erkan (kamil.erkan@marmara.edu.tr)
}

Received: 7 January 2014 - Published in Solid Earth Discuss.: 30 January 2014

Revised: 10 November 2014 - Accepted: 12 November 2014 - Published: 30 January 2015

\begin{abstract}
Determination of the conductive heat flow in western Anatolia has broad implications in many areas, including studies on the present-day extensional tectonic activity and assessments of the geothermal resources in the region. In this study, high-resolution equilibrium temperatures from 113 boreholes with depths of $\sim 100 \mathrm{~m}$ were analyzed for determination of the conductive heat flow. Thermal conductivities were either determined by measurements on outcrops or estimated using lithologic records. By a detailed analysis of temperature-depth curves, a total of 55 sites were selected as being useful for further conductive gradient/heat flow calculations, while the remaining 58 sites were abandoned due to hydrological effects on temperatures. Heat flow values with formal errors were calculated for 24 sites where rock thermal conductivity information is available. Due to the shallow depths of the investigated boreholes and uncertainties in thermal conductivity information, the results include a large accumulated error. A preliminary heat flow map is generated using the results of this study and a previous study in the southern Marmara region. Elevated heat flow values of $85-95 \mathrm{~mW} \mathrm{~m}^{-2}$ are observed in the coastal areas, including peninsular parts of Çanakkale and Izmir. The central part of the Menderes Massif also shows elevated heat flow values, the highest values $\left(>100 \mathrm{~mW} \mathrm{~m}^{-2}\right)$ being in the northeastern part of the Gediz Graben near the Kula volcanic center. Moderate heat flow values of $55-70 \mathrm{~mW} \mathrm{~m}^{-2}$ are observed in the eastern part of Çanakkale, central part of Balıkesir, northwest of Manisa, and northeast end of Bursa including Yalova. Some of the observed moderate values may be related to unconstrained near surface phenomena due to shallow depth of measurements. Towards the south of the study region, moderate heat flow values are also observed in Muğla. Previously reported regional heat flow values exceeding $\sim 120 \mathrm{~mW} \mathrm{~m}^{-2}$
\end{abstract}

is not observed in the region. The heat flow values reported in this study are comparable to the previously reported values in the Aegean Sea, as the two regions form the back-arc section of the Hellenic subduction zone.

\section{Introduction}

Determination of the conductive heat flow near the surface of the earth has many important applications, such as understanding the recent history of plate tectonic activity (Erkan and Blackwell, 2008, 2009), determining the depth of brittle/ductile transition in the crust (Bonner et al., 2003), and estimating the geothermal energy potential of a region (Tester et al., 2006; Serpen et al., 2009).

Western Anatolia is a unique region with intense presentday plate tectonic activity (Dilek and Altunkaynak, 2009). With the Aegean Sea, the two regions form the back-arc area of the Hellenic subduction zone (Jolivet et al., 2013). The region has been characterized by crustal extension and subduction-related andesitic volcanism since the Oligocene (Fytikas et al., 1984). Volcanism and extension have migrated southward with the southward retreat of the Hellenic subduction zone. The crustal extension in the region is considered to have two major phases: an early phase of nearly E$\mathrm{W}$ directed extension from the Miocene to the early Pliocene, and a second phase of $\mathrm{N}-\mathrm{S}$ extension during the Pliocene and the Quaternary. The latter resulted in the formation of modern horst/graben structures observed in the Menderes Massif (Koçyiğit et al., 1999).

The region has also been the locus of geothermal energy development, as it includes the highest enthalpy geothermal systems found in Turkey (Serpen et al., 2009). The highest 
temperature $\left(120-240{ }^{\circ} \mathrm{C}\right)$ geothermal systems have formed along the margins of the deep grabens of the Menderes Massif. These high temperatures were linked to the circulation of surface waters through deeply incised faults and the high heat flow from the basement of the Menderes horst-graben system.

The conventional method of heat flow determination requires high-resolution temperatures-versus-depth $(T-D)$ measurements in thermally stable boreholes, and thermal conductivity determinations on representative rocks (Beardsmore and Cull, 2001). In western Anatolia, heat flow studies based on the conventional techniques have been very limited. A heat flow map of the region is available as part of the heat flow map of Turkey (Tezcan and Turgay, 1991), which uses non-equilibrium bottom-hole-temperature (BHT) data and a constant thermal conductivity. In the southern Marmara region, Pfister et al. (1998) reported results of equilibrium $T-D$ data from shallow $(\sim 100 \mathrm{~m})$ boreholes, and thermal conductivity measurements from surface outcrops. Their results were included in making the preliminary heat flow map in this study (Fig. 4).

In this work, $T-D$ measurements from 113 shallow (depths of $\sim 100 \mathrm{~m}$ ) boreholes in western Anatolia are studied. Thermal conductivities were either measured on surface outcrops, or estimated from borehole lithologic information. As a result of processing the data, gradients and/or heat flow values were calculated for 55 points. A preliminary heat flow map of the region is generated and compared with results of previous studies.

\section{Data collection}

From 1995 to 1999, a regional campaign of collection of temperatures in boreholes and rock thermal conductivities was conducted in western and central Anatolia, for the determination of conductive heat flow (Ilkışık et al., 1996a, b). Data collection was performed by a group at the General Directorate of Mineral Research and Exploration (MTA) of Turkey. The boreholes were provided by the State Hydrological Works (DSI) and Rural Services (presently, out of service) regional offices. These boreholes were either drilled as water supply wells (but not producing), or as groundwater monitoring wells. Among the available boreholes, ones far from the known geothermal areas and located on bedrock were especially chosen (Öztürk et al., 2006). For each borehole, location, depth, lithologic records, static levels, etc., were obtained from the personnel of the state agencies. The holes were generally $6-8 \mathrm{inch}(15-20 \mathrm{~cm})$ in radius at the collar, and cased the entirety of their depths, with perforations at certain levels. Behind the casing, pebbles were used as the filling material to allow permeability between the borehole and the formation (H. M. Yenigün, personal communication, 2012).
$T-D$ data were collected for each meter of depth, using an Amerada surface read-out portable logging tool. Static water levels were determined by a sinker before each $T-$ $D$ measurement. All $T-D$ measurements were done below the water table. For thermal conductivity analysis, rock samples were collected from surface outcrops in the vicinity of each borehole. The measurements were run by a QTM-500 thermal conductivity device on dry samples. Generally, more than one type of lithology was sampled for each site, resulting in a larger data set for thermal conductivity measurements. A statistical analysis of these thermal conductivity measurements versus lithology is given by Balkan et al. (2015).

\section{Data analysis}

\subsection{Data quality classification}

Not all boreholes are suitable for conductive heat flow determinations. Quality of determination depends on the physical conditions of the borehole site. In this study, data were divided into various quality classes by analyzing the general characteristics of the $T-D$ curves. The criteria for each class and the associated numerical error in gradient calculations are summarized in Table 1.

Class A or B data are the ones that strictly satisfy the solution of 1-D heat transfer along a borehole (Jaeger, 1965). These include linearly increasing temperatures with depth, and projected surface temperature matching the mean annual surface temperature (MAST) of the measurement site. The projected surface temperature (the extrapolated value of the linear gradient at the surface) primarily depends on the latitude and the elevation of the borehole site, if no secondary effects exist due to microclimatic conditions (Roy et al., 1972). Another indication of a conductive section is that an increase/decrease in rock thermal conductivity results in a decrease/increase in the gradient, giving a constant heat flow along the borehole.

In some boreholes, vertical motion of the borehole fluid in some sections results in disturbed $T-D$ profiles, even though sections outside of the disturbed zone indicate conductive heat transfer (Roy et al., 1972; Erkan et al., 2008). Intraborehole fluid flow (IBF) occurs in open (not grouted) boreholes and causes sharp changes in $T-D$ curves where the fluids enter and exit the borehole. These types of data were rated class $\mathrm{C}$, with a larger $(25 \%)$ relative error in gradient calculations. If IBF dominates most of the $T-D$ profile, gradient calculations have uncertain reliability (class $\mathrm{D}$, no error bound). In these boreholes, gradients are either constrained from a few control points, or calculated at very shallow $(<50 \mathrm{~m})$ depths.

Borehole sites not suitable for conductive heat flow analysis are rated class $X$. These sites show the effect of local hydrologic activity and conductive thermal regime is overprinted by the groundwater motion. $T-D$ curves for these 
holes were generally observed to show isothermal behavior, indicating fast vertical flow. Other types of hydrologically active sites are found near geothermal systems. These sites show the effect of local geothermal activity, which shows distinctly higher temperatures. These types of data are rated class $G$, and are also not suitable for conductive heat flow determinations.

The regional distribution of all the data according to the quality classes is shown in Fig. 1. Out of 113 sites, 58 of them fall into class $\mathrm{X}$ or $\mathrm{G}$, and are not suitable for conductive heat flow analysis. 24 sites fall into class $\mathrm{D}$, and the remaining 31 sites fall into classes $\mathrm{A} / \mathrm{B} / \mathrm{C}$.

\subsection{Temperature-depth curves}

The administrative provinces in Turkey have moderate sizes, and are suitable for comparative analysis of $T-D$ curves (Fig. 1). For example, due to the proximity of the sites, projected surface temperatures can be compared directly with their elevations. $T-D$ curves for class $\mathrm{A}, \mathrm{B}$, and $\mathrm{C}$ data are shown in various panels of Fig. 2, based on the provinces in which they are located.

In Çanakkale (Fig. 2a), $T-D$ curves show generally conductive behavior for entire lengths, and the effect of IBF is minimal. A weak downflow (33-50 m) in Pazarkoy, a strong upflow (95-125 m) in Cavuskoy, and a strong upflow (90$130 \mathrm{~m}$ ) in Ortuluce are inferred. Projected surface temperatures correlate well with elevations. (Fig. 1) For example, Intepe and Cavuskoy are located near the sea shore, and have the highest projected surface temperatures. On the other hand, Pazarkoy and Terzialan are located farther inland, at higher elevations; they show relatively lower projected surface temperatures (an adiabatic lapse rate of $5^{\circ} \mathrm{C} \mathrm{km}^{-1}$ may be used for correlating elevations with surface temperatures). In Yapildak, a downflow from the surface to $25 \mathrm{~m}$ must have been occurring for a long time, so that the $z=25 \mathrm{~m}$ level acts as the apparent surface of the borehole. The $T-D$ curve below this level shows the conductive thermal regime. Another interesting feature is the sharp break in the gradients for Intepe at $65 \mathrm{~m}$. Lithologic records show a change from claystone to diabase lithology around this depth, which should result in this abrupt change in the gradient.

$T-D$ curves for Bursa and Balikesir are shown in Fig. $2 \mathrm{~b}$. In Bursa, when compared to the other two sites, Eyerce is located about $300 \mathrm{~m}$ higher, which may explain the lower projected temperature for this hole.

For Izmir (Fig. 2c), holes are relatively shallower, but they show a conductive thermal regime for their entire depths. For Yusufdere, the first $50 \mathrm{~m}$ of the hole seem to be affected by hydrologic disturbances; below $50 \mathrm{~m}$, a conductive regime is apparent. Bademli penetrates a very highly conductive sandstone lithology $\left(4.1 \mathrm{~W} \mathrm{~m}^{-1} \mathrm{~K}^{-1}\right)$, which may be responsible for the low gradients in this hole. For three holes in Fig. 2c, near-surface systematic changes toward higher temperatures at their first $\sim 50 \mathrm{~m}$ in depth are interesting (see deviations

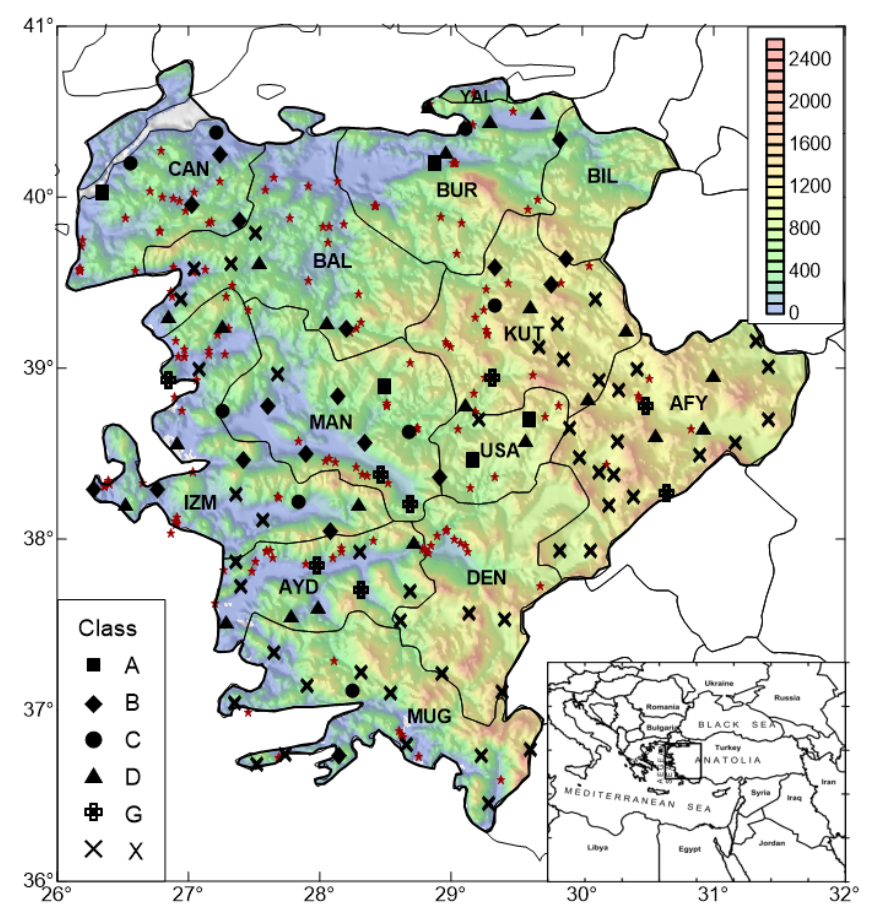

Figure 1. Data locations with the corresponding quality classes. See the text for details of the class definitions. Red star symbols show locations of hot springs. Elevations are in meters. Acronyms for administrative provinces are as follows: CAN: Çanakkale; BAL: Balıkesir; BUR: Bursa; BIL: Bilecik; KUT: Kütahya; MAN: Manisa; USA: Uşak; AFY: Afyon; IZM: Izmir; DEN: Denizli; AYD: Aydın; MUG: Muğla.

from the dashed lines in Yenmis, Ovaciki, and Ciftlikkoy). These changes may be due to recent changes in the MAST values. It is known that some holes (ones belonging to Rural Services) were protected in small rooms, which may cause a transient microclimatic effect (i.e., greenhouse heating) on the surface. The depths of these deviations indicate the time periods these rooms were built.

$T-D$ curves for Manisa (Fig. 2d) show some local fluctuations, but their general character shows conductive behavior. If these fluctuations are not instrumental, they may be due to cellular convections inside the borehole caused by the application of the sinker before the measurement. Cellular convections are formed when the borehole diameter is larger than a certain size, which may be the case for Manisa (see Pfister et al., 1998, for a more detailed discussion about cellular convections). The projected surface temperatures are consistent with each other, but they seem to have systematically higher values compared to the values in Izmir. If MAST values are not really higher in Manisa, this shift may indicate a calibration problem in the $T-D$ measurement tool.

$T-D$ curves for Kütahya and Uşak provinces show generally linear behavior (Fig. 2e). An elevation difference of $\sim 500 \mathrm{~m}$ between the two provinces results in a $3-4{ }^{\circ} \mathrm{C}$ difference for projected surface temperatures. In Koprucek, a 
Table 1. Definitions of the data quality classes used in this study.

\begin{tabular}{llc}
\hline Class & Description & Estimated relative error in gradient \\
\hline $\mathrm{A}$ & $>100$ m conductive (linear) $T-D$ section & $5 \%$ \\
$\mathrm{~B}$ & $>50$ m conductive (linear) $T-D$ section & $10 \%$ \\
$\mathrm{C}$ & Disturbed $T-D$ curve due to intra-borehole fluid activity & $25 \%$ \\
& Intermittent conductive sections & - \\
$\mathrm{D}$ & Intense intra-borehole fluid activity; conductive section too shallow & - \\
$\mathrm{G}$ & $T-D$ curve overprinted by geothermal activity & - \\
$\mathrm{X}$ & $T-D$ curve overprinted by groundwater activity & \\
\hline
\end{tabular}

downflow or lateral flow seems to be occurring in the first $75 \mathrm{~m}$ of the borehole; below this depth, it is conductive. In Muğla (Fig. 2f), conductive behavior was observed in two holes among many visited holes (see Fig. 1).

\section{Results}

Calculated temperature gradients and their interval depths are given in Table 2, along with other useful information. Errors for gradient calculations were calculated based on the criteria in Table 1. For some sites, mostly for class D data, gradients were calculated by drawing a hypothetical line for the entire depth, and their intervals are shown to start at the surface in Table 2. Terrain correction was applied to some boreholes using Lee's topographic correction model (Beardsmore and Cull, 2001). In this model, the topography is fitted to a 2-D mountain range or a hill characterized by a certain height and width. The correction resulted in changes of up to $10^{\circ} \mathrm{C} \mathrm{km}^{-1}$ in gradient. The error from the 2-D assumption of the topography is considered to be negligible compared to the error bounds for the gradients in Table 1. The regional distribution of the (corrected) gradient calculations and their errors is shown in Fig. 3a.

Thermal conductivities were determined based on the lithologic data for the interval where gradients were calculated. Measurements were made on surface outcrops under dry conditions, so they had to be corrected for wet conditions. The geometric mixing model was applied for the porosity correction (Fuchs et al., 2013). For porosities of sedimentary rocks, the values reported by Fuchs et al. (2013) were used. For volcanic and metamorphic rocks, porosity values of 5 and $4 \%$ were used, respectively (JICA, 1987). In order to account for uncertainties in porosity assumptions, an additional error of $25 \%$ was assumed for all porosities, and this error was propagated to the error in bulk thermal conductivity estimations. When no thermal conductivity measurements were available, literature values and their respective error bounds were used (Balkan et al., 2015; Blackwell and Steele, 1989; Clark, 1966). For data located in Quaternary alluvium, a generic value of $1.5 \pm 0.3 \mathrm{~W} \mathrm{~m}^{-1} \mathrm{~K}^{-1}$ was used based on a statistical analysis (see the interactive comment, SED, 6, C78-C81).
The calculated heat flow values are given in Table 2 (25 points for classes $\mathrm{A} / \mathrm{B} / \mathrm{C}$ with their propagated error, and 11 points for class $\mathrm{D}$ data with no error bound). Regional distribution of the heat flow values is shown in Fig. 3b. With the exception of two holes in areas of active sedimentation (see discussion below), the average heat flow is calculated to be $73 \pm 22 \mathrm{~mW} \mathrm{~m}^{-2}$, based on class A/B/C-type data.

Depending on the geographic location, recent climatic changes can have a significant effect on measured heat flow values, and require further correction (Majorowicz and Wybraniec, 2010). In particular, at high latitudes, the Pleistocene ice age and the subsequent warming require corrections of up to $20 \mathrm{~mW} \mathrm{~m}^{-2}$ in heat flow determinations. For Turkey, effects of Holocene climatic change on heat flow measurements were calculated to be $2-4 \mathrm{~mW} \mathrm{~m}^{-2}$ (Majorowicz and Wybraniec, 2010). The correction would be smaller for gradients measured at shallow depths, as the warming would affect the entirety of the section (see Majorowicz and Wybraniec, 2010, Fig. 2). On the other hand, more recent changes (last 100 years) in the climate require more attention for gradients measured at shallow boreholes. Tayanç et al. (2009) report no significant change in the mean annual temperatures in Turkey until 1993, and an accumulated warming of $\sim 0.5^{\circ} \mathrm{C}$ since then. The effect of this warming trend on gradients may be estimated using the chart given by Pollack and Huang (2000, Fig. 3). According to this, a unit change in the surface temperature in the last $\sim 20$ years penetrates into the subsurface down to $\sim 50 \mathrm{~m}$, with exponentially decreasing magnitude. Gradient measurements below $50 \mathrm{~m}$ of the borehole would not be affected by the recent warming trend at all. Above this depth, and below the zone of annual temperature effects (below $20 \mathrm{~m}$ ), the recent warming is expected to have a disturbance of $\sim 0.1^{\circ} \mathrm{C}$. For a $30 \mathrm{~m}$ long linear section and thermal conductivity of $1.5 \mathrm{~W} \mathrm{~m}^{-1} \mathrm{~K}^{-1}$, this would result in an error of up to $5 \mathrm{~mW} \mathrm{~m}^{-2}$ in heat flow calculations. This value is well within the error bounds reported for the present heat flow determinations. 

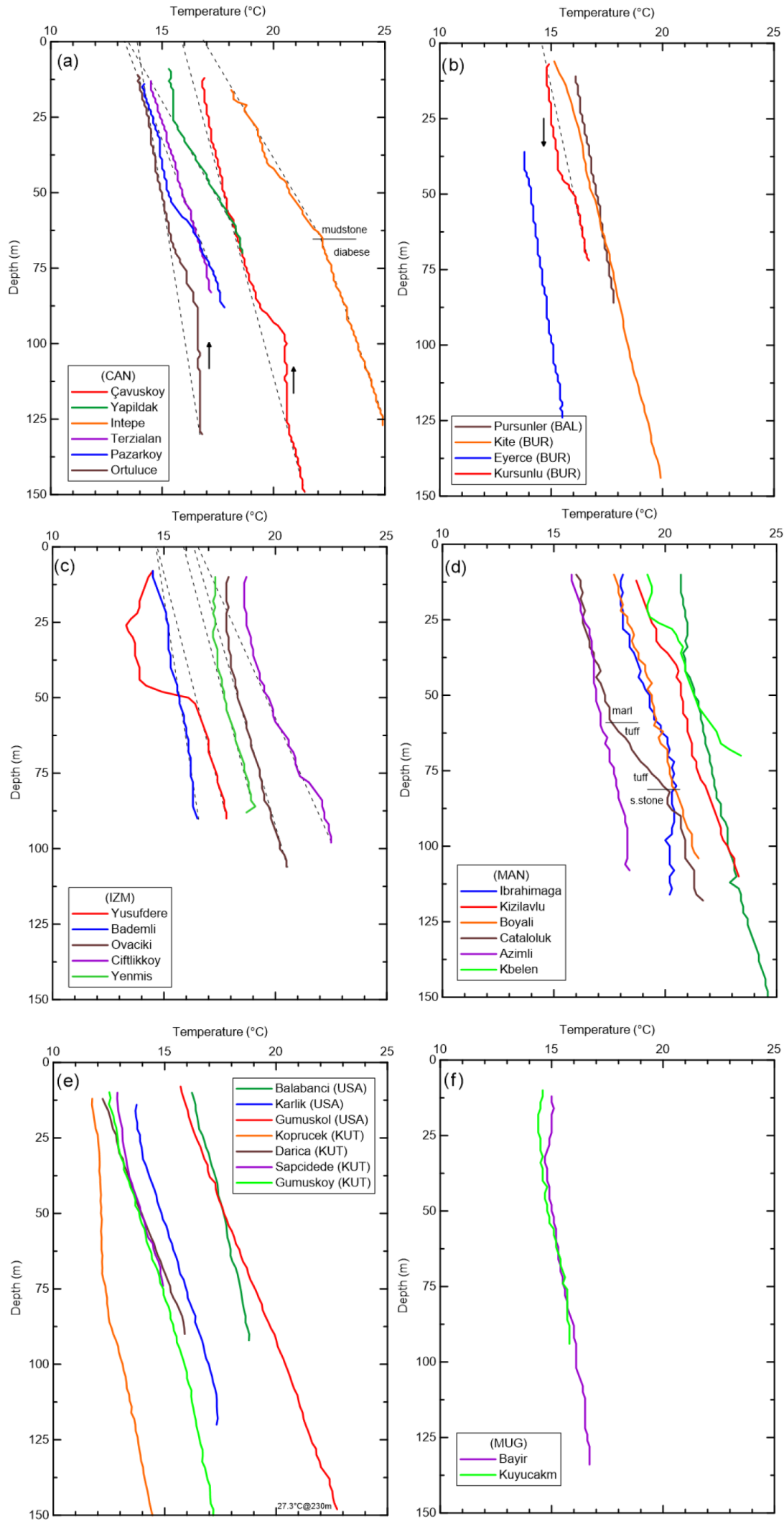

Figure 2. Temperature-depth $(T-D)$ curves for classes A/B/C data for the provinces of (a) Çanakkale, (b) Balıkesir/Bursa, (c) Izmir, (d) Manisa, (e) Uşak/Kütahya, and (f) Muğla. Vertical arrows show the inferred direction of intra-borehole fluid flow. 
Table 2. Class (A/B/C/D)-type data used in this study, along with gradients, thermal conductivities, heat flow values, and their respective errors. For sites where thermal conductivities cannot be quantified, only gradients are listed. Gradient/heat flow values in parentheses are estimated values without formal error (for class D-type data). Literature thermal conductivities are indicated by (L) next to the value, and are obtained from Balkan et al. (2015), Blackwell and Steele (1989), and Clark (1966). Depth intervals starting with $z=0$ indicate that the gradient is calculated based on a hypothetic line using the projected mean annual surface temperature. See the caption of Fig. 1 for administrative province names; $G$ : geothermal gradient; $K$ : thermal conductivity; $Q$ : (corrected) heat flow.

\begin{tabular}{|c|c|c|c|c|c|c|c|c|c|c|c|c|c|c|c|}
\hline \multirow[t]{2}{*}{ Site name } & \multirow{2}{*}{$\begin{array}{l}\text { Latitude } \\
\qquad\left({ }^{\circ} \mathrm{E}\right)\end{array}$} & \multirow{2}{*}{$\begin{array}{l}\text { Longitude } \\
\left({ }^{\circ} \mathrm{N}\right)\end{array}$} & \multirow[t]{2}{*}{ Prov. } & Elev. & Depth & \multirow[t]{2}{*}{ Class } & \multirow{2}{*}{$\begin{array}{c}\text { Interval } \\
\text { (m) }\end{array}$} & \multirow{2}{*}{\multicolumn{2}{|c|}{$\begin{array}{lr}G \quad & \text { Corr. } G \\
& \left({ }^{\circ} \mathrm{Ckm}^{-1}\right)\end{array}$}} & \multirow[t]{2}{*}{$\sigma G$} & \multirow{2}{*}{\multicolumn{2}{|c|}{$\frac{K \quad \sigma K}{\left(\mathrm{~W} \mathrm{~m} \mathrm{~K}^{-1}\right)}$}} & $Q$ & $\sigma Q$ & \multirow[t]{2}{*}{ Lithology } \\
\hline & & & & $(\mathrm{m})$ & $(\mathrm{m})$ & & & & & & & & $(\mathrm{mW}$ & $n^{-2}$ ) & \\
\hline Kadikoy & 38.6365 & 30.9175 & AFY & 979 & 106 & $\mathrm{D}$ & $0-106$ & $(49.1)$ & & & & & & & \\
\hline Agzikara & 38.5900 & 30.5600 & AFY & 1284 & 110 & $\mathrm{D}$ & $0-110$ & $(36.4)$ & & & & & & & \\
\hline Calislar & 38.8100 & 30.0400 & AFY & 1228 & 114 & $\mathrm{D}$ & $0-114$ & (30.4) & (36.4) & & & & & & \\
\hline Derbent & 38.9400 & 31.0000 & AFY & 1238 & 176 & $\mathrm{D}$ & $120-156$ & (31.9) & & & & & & & \\
\hline Tekeler & 37.5406 & 27.7799 & AYD & 546 & 94 & $\mathrm{D}$ & 0-94 & $(21.3)$ & & & 1.9 & 0.2 & (41) & & Schist \\
\hline Ortakci & 37.9700 & 28.7200 & AYD & 211 & 112 & $\mathrm{D}$ & $66-112$ & $(28.3)$ & & & & & & & \\
\hline Kargili & 37.5877 & 27.9921 & AYD & 81 & 100 & $\mathrm{D}$ & 0-98 & (26.5) & & & & & & & \\
\hline Balat & 37.4978 & 27.2848 & AYD & 20 & 96 & D & $80-95$ & $(40.0)$ & & & $1.6(\mathrm{~L})$ & 0.4 & (64) & & Marl \\
\hline Pursunler & 39.2270 & 28.2017 & BAL & 294 & 86 & B & $13-82$ & 24.6 & 28.5 & 2.9 & 2.0 & 0.2 & 57 & 11 & Andesite \\
\hline Alacaatli & 39.2534 & 28.0488 & BAL & 262 & 71 & $\mathrm{D}$ & $0-71$ & (19.7) & $(24.5)$ & & $1.8(\mathrm{~L})$ & 0.6 & (44) & & Andesite \\
\hline Akcal & 39.6038 & 27.5416 & BAL & 250 & 100 & $\mathrm{D}$ & $0-100$ & $(23.0)$ & $(37.1)$ & & & & & & \\
\hline Bulutlucesme & 39.2851 & 26.8492 & BAL & 328 & 92 & $\mathrm{D}$ & $0-40$ & (29.3) & $(42.0)$ & & $1.8(\mathrm{~L})$ & 0.6 & (76) & & Andesite \\
\hline Kite & 40.1972 & 28.8763 & BUR & 74 & 156 & A & $20-148$ & 32.5 & & 1.6 & $1.5(\mathrm{~L})$ & 0.3 & 49 & 12 & Q. aluvium \\
\hline Eyerce & 40.3375 & 29.8281 & BUR & 372 & 124 & B & $38-124$ & 19.8 & & 2.0 & 3.7 & 0.2 & 73 & 11 & Marble \\
\hline Kursunlu & 40.4014 & 29.1105 & BUR & 15 & 72 & $\mathrm{C}$ & $50-70$ & 30.0 & & 7.5 & $1.5(\mathrm{~L})$ & 0.3 & 45 & 20 & Q. aluvium \\
\hline Linyit & 40.2512 & 28.9616 & BUR & 91 & 94 & $\mathrm{D}$ & $72-94$ & (22.6) & & & & & & & \\
\hline Cakirca & 40.4762 & 29.6630 & BUR & 94 & 124 & $\mathrm{D}$ & $0-124$ & $(29.0)$ & & & $1.5(\mathrm{~L})$ & 0.3 & (44) & & Q. aluvium \\
\hline As.Vet. & 40.3980 & 29.0986 & BUR & 11 & 40 & $\mathrm{D}$ & $24-38$ & (47.5) & & & $1.5(\mathrm{~L})$ & 0.3 & (71) & & Q. aluvium \\
\hline Gurle & 40.4313 & 29.2987 & BUR & 102 & 118 & $\mathrm{D}$ & $54-118$ & $(87.5)$ & & & & & & & \\
\hline Intepe & 40.0279 & 26.3434 & CAN & 151 & 127 & A & $69-124$ & 42.6 & 43.6 & 2.2 & $2.1(\mathrm{~L})$ & 0.3 & 92 & 18 & Diabase \\
\hline Pazarkoy & 39.8647 & 27.3855 & CAN & 162 & 88 & B & $15-82$ & 50.7 & & 5.1 & $1.5(\mathrm{~L})$ & 0.3 & 76 & 23 & Q. aluvium \\
\hline Terzialan & 39.9565 & 27.0234 & CAN & 152 & 83 & B & $17-73$ & 41.4 & & 4.1 & $1.0(\mathrm{~L})$ & 0.2 & 41 & 12 & Claystone \\
\hline Cavuskoy & 40.2480 & 27.2407 & CAN & 21 & 162 & $\mathrm{~B}$ & $125-162$ & 32.4 & & 3.2 & $1.5(\mathrm{~L})$ & 0.3 & 49 & 15 & Q. aluvium \\
\hline Yapildak & 40.2005 & 26.5561 & CAN & 140 & 70 & $\mathrm{C}$ & $27-65$ & 76.3 & 85.3 & 21.3 & $1.0(\mathrm{~L})$ & 0.2 & 85 & 38 & Claystone \\
\hline Ortuluce & 40.3780 & 27.2111 & CAN & 58 & 130 & $\mathrm{C}$ & $0-130$ & 23.1 & & 5.8 & $2.5(\mathrm{~L})$ & 0.5 & 58 & 26 & Conglomerate \\
\hline Ciftlikkoy & 38.2879 & 26.2796 & IZM & 51 & 98 & B & $32-74$ & 50.0 & & 5.0 & 1.7 & 0.1 & 85 & 14 & Marl \\
\hline Ovaciki & 38.2898 & 26.7599 & IZM & 137 & 106 & $\mathrm{~B}$ & $46-106$ & 38.3 & 49.0 & 4.9 & $1.7(\mathrm{~L})$ & 0.4 & 83 & 28 & Marl \\
\hline Yenmis & 38.4597 & 27.4172 & IZM & 189 & 88 & B & $48-82$ & 35.3 & & 3.5 & $1.5(\mathrm{~L})$ & 0.3 & 53 & 16 & Q. aluvium fan \\
\hline Bademli & 38.0500 & 28.0792 & IZM & 364 & 90 & B & $20-90$ & 21.4 & & 2.1 & 4.1 & 0.5 & 88 & 19 & Sandstone \\
\hline Yusufdere & 38.2172 & 27.8396 & IZM & 128 & 90 & $\mathrm{C}$ & $52-88$ & 38.9 & 33.6 & 8.4 & 1.5 & 0.3 & 50 & 23 & Q. aluvium fan \\
\hline Haliller & 38.1883 & 28.2960 & IZM & 328 & 100 & $\mathrm{D}$ & $86-100$ & $(28.6)$ & & & 1.5 & 0.3 & (43) & & Q. aluvium fan \\
\hline Y. Kiriklar & 39.2315 & 27.2549 & IZM & 357 & 154 & $\mathrm{D}$ & $46-134$ & (48.9) & & & $1.6(\mathrm{~L})$ & 0.4 & (78) & & Marl \\
\hline Seyrek & 38.5500 & 26.9173 & IZM & 5 & 174 & $\mathrm{D}$ & $40-96$ & $(51.8)$ & & & $1.6(\mathrm{~L})$ & 0.4 & (83) & & Marl \\
\hline Zeytineli & 38.1917 & 26.5250 & IZM & 300 & 82 & $\mathrm{D}$ & $38-68$ & (33.3) & & & 2.7 & 0.3 & (90) & & Limestone \\
\hline Gumuskoy & 39.4882 & 29.7627 & KUT & 1037 & 156 & B & $28-89$ & 34.5 & & 3.5 & & & & & \\
\hline Sapcidede & 39.5884 & 29.3348 & KUT & 1014 & 74 & B & $36-74$ & 40.3 & & 4.0 & & & & & \\
\hline Darica & 39.6380 & 29.8707 & KUT & 1165 & 90 & B & $40-78$ & 50.3 & & 5.0 & & & & & \\
\hline Koprucek & 39.3660 & 29.3349 & KUT & 1046 & 158 & $\mathrm{C}$ & $100-150$ & 26.8 & 27.7 & 6.9 & & & & & \\
\hline Esatlar & 39.3439 & 29.6016 & KUT & 938 & 88 & $\mathrm{D}$ & $0-88$ & $(47.0)$ & & & & & & & \\
\hline Tepekoy & 39.2100 & 30.3300 & KUT & 1100 & 182 & $\mathrm{D}$ & $0-182$ & (30.9) & & & & & & & \\
\hline Cataloluk & 38.8943 & 28.4907 & MAN & 676 & 122 & A & $90-122$ & 25.0 & & 1.3 & 3.5 & 0.5 & 88 & 17 & Sandstone \\
\hline Kizilavlu & 38.5649 & 28.3404 & MAN & 289 & 110 & B & $70-110$ & 52.5 & & 5.3 & $1.5(\mathrm{~L})$ & 0.3 & 79 & 24 & Q. aluvium \\
\hline Alahidir & 38.5000 & 27.8974 & MAN & 145 & 182 & $\mathrm{~B}$ & $114-182$ & 36.8 & & 3.7 & $1.5(\mathrm{~L})$ & 0.3 & 55 & 17 & Q. aluvium fan \\
\hline Boyali & 38.8338 & 28.1418 & MAN & 502 & 104 & B & $20-104$ & 40.5 & & 4.1 & 1.3 & 0.1 & 53 & 9 & Alluvium \\
\hline Azimli & 38.7774 & 27.6073 & MAN & 101 & 108 & B & $52-94$ & 33.3 & & 3.3 & 1.5 & 0.3 & 50 & 15 & Q. aluvium \\
\hline Ibrahimaga & 38.6284 & 28.6784 & MAN & 509 & 152 & $\mathrm{C}$ & $28-64$ & 55.6 & & 13.9 & 2.4 & 0.2 & 133 & 45 & Schist \\
\hline K. Belen & 38.7500 & 27.2583 & MAN & 370 & 74 & $\mathrm{C}$ & $0-66$ & 57.6 & & 14.4 & $1.8(\mathrm{~L})$ & 0.6 & 104 & 60 & Andesite/tuff \\
\hline Bayir & 36.7347 & 28.1509 & MUG & 185 & 134 & B & $40-126$ & 20.9 & & 2.1 & 3.5 & 0.3 & 73 & 14 & Limestone \\
\hline Kuyucakm & 37.1119 & 28.2496 & MUG & 760 & 94 & $\mathrm{C}$ & $46-76$ & 32.3 & & 8.1 & 2.0 & 0.2 & 65 & 23 & Limestone \\
\hline Gumuskol & 38.4627 & 29.1657 & USA & 895 & 230 & A & 19-108 & 52.1 & & 2.6 & & & & & \\
\hline Karlik & 38.7001 & 29.5954 & USA & 1066 & 120 & $\mathrm{~A}$ & $34-104$ & 42.3 & & 2.1 & & & & & \\
\hline Balabanci & 38.3618 & 28.9149 & USA & 716 & 92 & B & $20-50$ & 38.0 & & 3.8 & & & & & \\
\hline Karakuyu & 38.7680 & 29.1116 & USA & 789 & 114 & $\mathrm{D}$ & $0-108$ & $(56.1)$ & & & & & & & \\
\hline Salmanlar & 38.5600 & 29.5700 & USA & 925 & 56 & $\mathrm{D}$ & $44-52$ & $(52.0)$ & & & & & & & \\
\hline Armutlu & 40.5158 & 28.8264 & YAL & 9 & 79 & $\mathrm{D}$ & $0-79$ & (27.8) & & & $1.5(\mathrm{~L})$ & 0.3 & (42) & & Q. aluvium \\
\hline
\end{tabular}

\section{Discussion}

A preliminary contour map of the heat flow values was generated by combining data in Table 2 (using class $\mathrm{A} / \mathrm{B} / \mathrm{C}$ data) and the previous results of Pfister et al. (1998) in the southern Marmara region. For the Pfister et al. (1998) data, values outside the range of $40-140 \mathrm{~mW} \mathrm{~m}^{-2}$ were eliminated due to possible hydrologic disturbances. Furthermore, for three 

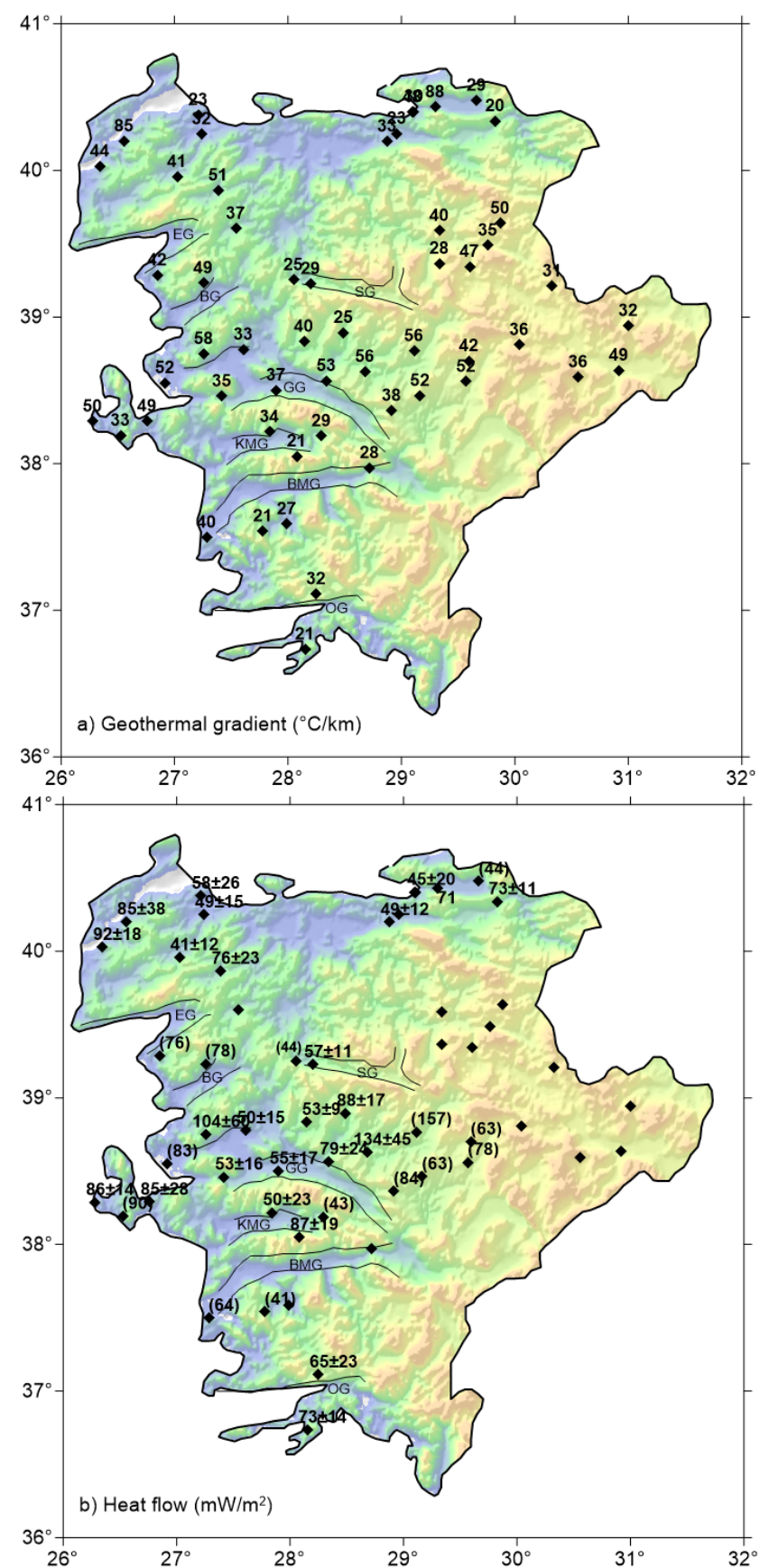

Figure 3. Regional distribution of the (a) geothermal gradients and (b) heat flow values in Table 2. Note that some sites only have gradient values due to the unavailability of thermal conductivity information. Black lines indicate boundaries of horst-graben structures, which are the dominant structural features in the region. GG: Gediz Graben; BMG: Büyük Menderes Graben; KMG: Küçük Menderes Graben; EG: Edremit Graben; BG: Bakırçay Graben; SG: Simav Graben; OG: Gökova Graben.

points located on alluvial fans within the Menderes Massif (Table 2), corrections for sedimentation and thermal refraction were applied before mapping (discussed below in de-

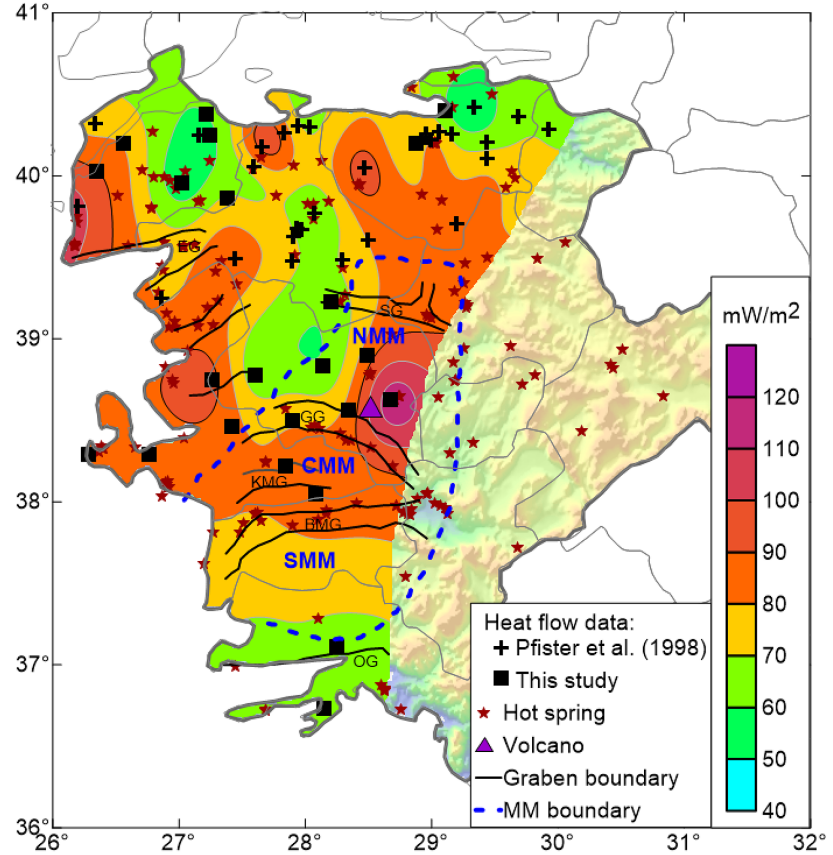

Figure 4. The preliminary heat flow map of the region using the results of this study (class $\mathrm{A} / \mathrm{B} / \mathrm{C}$ data in Table 2), and of Pfister et al. (1998). Blue lines outline the boundary of the Menderes Massif. The blue triangle indicates the location of the Kula volcanic center.

tail). The gridding was done using the minimum curvature technique with a grid spacing of $0.02^{\circ}$ in both directions. Then, a 2-D isotropic Gaussian filter of radius $30 \mathrm{~km}$ was applied. The resulting heat flow map is shown in Fig. 4. The boundary of the Menderes Massif is also shown in Fig. 4 (blue dashed lines). In the discussions below, the Menderes Massif is divided into three units: the northern Menderes Massif (NMM), the central Menderes Massif (CMM), and the southern Menderes Massif (SMM), separated by two major graben units, the Gediz Graben (GG), which are and the Büyük Menderes Graben (BMG).

The preliminary heat flow map outlines regions with moderate $\left(55-70 \mathrm{~mW} \mathrm{~m}^{-2}\right)$ and elevated $\left(85-95 \mathrm{~mW} \mathrm{~m}^{-2}\right)$ heat flow values. Moderate heat flow values are observed in the interior parts of the southern Marmara region (east of Çanakkale, center of Balıkesir, and northeast of Bursa including Yalova), and northwest of Manisa. Also, at the southern end of the mapped area (in Muğla), heat flow values get moderate values. On the other hand, elevated heat flow values are observed in the western part of Çanakkale, the peninsular part of Izmir, and the central part of the Menderes Massif. The area of highest $\left(>100 \mathrm{~mW} \mathrm{~m}^{-2}\right)$ heat flow is in the northeastern part of the Gediz Graben, which is near with the observed area of the most recent volcanic activity (Kula volcanic field, see the triangle in Fig. 4); however, data control is low there. 


\subsection{Effects of sedimentation/erosion and thermal refraction}

Heat flow measured in areas of active extension shows nearsurface variations due to active sedimentation/erosion and thermal refraction (Blackwell, 1983). Within the studied region, the horst-graben system of Menderes Massif is expected to show the significant thermal effects of sedimentation/erosion and thermal refraction.

Sedimentation causes a downward motion of low temperatures at the surface, resulting in lower-than-normal surface heat flow values (Beardsmore and Cull, 2001). Sedimentation rates within the grabens can be calculated using the results of sedimentological studies. According to this, the modern Gediz Graben is Plio-Quaternary $(\sim 5 \mathrm{Myr})$ in age (Koçyiğit, et al., 1999; Bozkurt and Sözbilir, 2004), and the thicknesses of the sediments accumulated during this time interval are 200-1000 m, depending on the location (Seyitoğlu and Scott, 1996; Bozkurt and Sözbilir, 2004; Çiftci and Bozkurt, 2010). A model of the surface heat flow versus sedimentation rate for the Menderes Massif is shown in Fig. 5 (the blue curve). The calculated sedimentation rates of 40-200 $\mathrm{m} \mathrm{Myr}^{-1}$ correspond to surface heat flow values 5$10 \mathrm{~mW} \mathrm{~m}^{-2}$ below the background values. However, the actual difference depends on the location where the heat flow is measured.

Erosion and denudation (collectively termed "erosion" in this text) cause an upward motion of high temperatures at depth, resulting in higher than normal surface heat flow values (Beardsmore and Cull, 2001). Erosion histories of different horst units of the Menderes Massif were estimated by radiometric dating and fission-track techniques (Gessner et al., 2001; Ring et al., 2003; see Seyitoğlu et al., 2004, for a review). These studies show an early phase of significant cooling during the late Oligocene and the early Miocene in NMM and SMM, but minimal present-day erosion rates. On the other hand, they report rapid cooling rates for the last $5 \mathrm{Myr}$ at the northern and southern edges (called detachment zones) of the CMM. The reported cooling rates of $\sim 50^{\circ} \mathrm{C} \mathrm{km}^{-1}$ (Gessner et al., 2001) correspond to erosion rates of $\sim 1000 \mathrm{~m} \mathrm{Myr}^{-1}$ for the last $5 \mathrm{Myr}$ in these areas. For a background heat flow of $85 \mathrm{~mW} \mathrm{~m}^{-2}$, surface surface heat flow in these detachment zones can have values of up to $130 \mathrm{~mW} \mathrm{~m}^{-2}$. However, no data points are available on these zones in the present data set.

Thermal refraction occurs near the boundaries of the horst and graben units, as a result of the thermal conductivity contrasts between the two structural units. By their low conductivity values, grabens act as thermal lenses, refracting the heat to their surroundings. Thakur et al. (2012) show the effect of thermal refraction in Dixie Valley in Nevada (North America), which has a comparable size and depth to Gediz Graben in Turkey. Compared to the background heat flow, their model shows up to $15 \mathrm{~mW} \mathrm{~m}^{-2}$ lower values in the

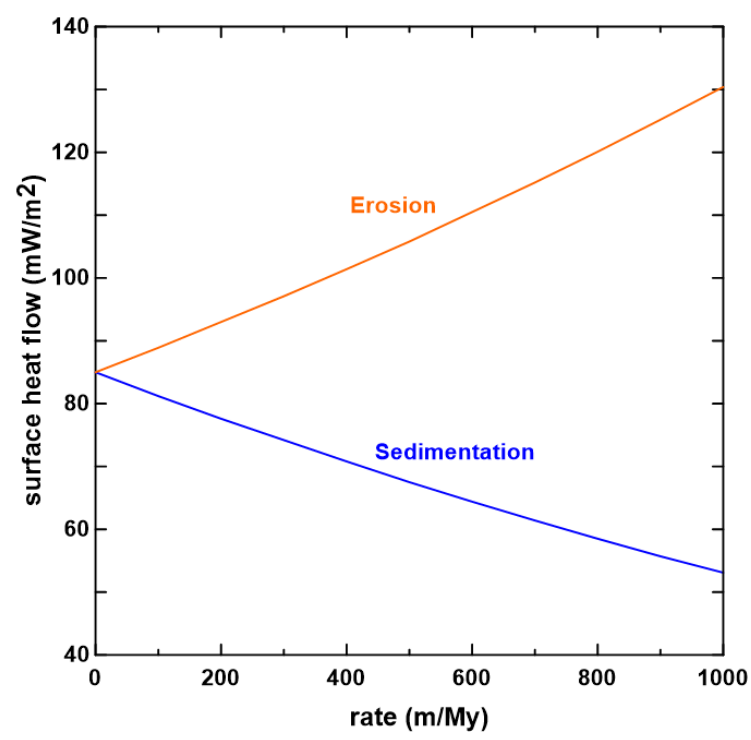

Figure 5. Changes in the surface heat flow in the Menderes Massif for increasing rates of sedimentation (blue line) and erosion (orange line). The graphs were prepared using the modules of G. Beardsmore (http://monash.edu/science/about/schools/ geosciences/heatflow/). See Beardmore and Cull (2001) for the formulation of the problem. The model assumes extensional activity for the last $5 \mathrm{Myr}$, a background heat flow of $85 \mathrm{~mW} \mathrm{~m}^{-2}$, and a thermal diffusivity of $1 \times 10^{-6} \mathrm{~m}^{2} \mathrm{~s}^{-1}$. Note that these models use a 1-D assumption for sedimentation/erosion.

graben, and up to $30 \mathrm{~mW} \mathrm{~m}^{-2}$ higher values in the ranges, as a result of thermal refraction.

In the present data set, three sites on the alluvial fans (see the lithology information in Table 2) within graben units of the Menderes Massif are expected to experience a significant thermal effect of sedimentation and thermal refraction. As a result, a constant cumulative correction of $30 \mathrm{~mW} \mathrm{~m}^{-2}$ was applied to these points before generating the heat flow map. No correction for erosion was necessary, due to the unavailability of data on the areas of significant present-day erosion.

\subsection{Heat flow versus maximum depth of seismicity in western Anatolia}

The heat flow map in Fig. 4 can be compared independently by the observed maximum depth of seismicity in the region. For this purpose, high-quality (depth errors less than $2 \mathrm{~km}$ ) hypocenter data from seismic studies are needed. Akyol et al. (2006) report hypocenter locations across a $\mathrm{N}-\mathrm{S}$ profile on the Menderes Massif. Their class-A events show a maximum depth of seismicity of $\sim 15 \mathrm{~km}$ in the central part of the CMM. Also, Aktar et al. (2007) report the results of a high-resolution survey in the southern part of the peninsular part of Izmir. The event depths go down to $\sim 13 \mathrm{~km}$ there. Bonner et al. (2003) report a statistical correlation between heat flow and seismic depths by comparing 
two separate high-resolution data sets in California. According to this, seismic depths of $\sim 15 \mathrm{~km}$ imply heat flow of $\sim 100 \mathrm{~mW} \mathrm{~m}^{-2}$ or less, and are in general agreement with the results of this study. One of the limitations of these comparisons is that the depth of the brittle zone cannot be constrained if seismicity does not cover the entire brittle zone, so the inferred heat flow values by seismic event depths only put a maxiumum limit on the heat flow value.

\subsection{Tectonic implications}

The region in this study is part of the back-arc area of the Hellenic subduction zone (Jolivet et al., 2013). With the Aegean Sea, the general area is characterized by extensional tectonic activity and elevated heat flow values. The general area is also characterized by a single low P-wave velocity anomaly (Piromallo and Morelli, 2003), indicating high temperatures at the lithospheric levels. In the Aegean Sea, Erickson et al. (1977) report an average heat flow of $80 \pm 22 \mathrm{~mW} \mathrm{~m}^{-2}$. The average heat flow $73 \pm 22 \mathrm{~mW} \mathrm{~m}^{-2}$ for western Anatolia reported in this study is comparable with the values measured in the Aegean Sea. Relatively lower average heat flow for western Anatolia can generally be attributed to moderate values observed in the southern Marmara region (see Fig. 5). On the other hand, parts of western Anatolia under active extension show heat flow values of $85-90 \mathrm{~mW} \mathrm{~m}^{-2}$.

Heat flow values reported in this study for western Anatolia is somewhat lower than the values given by Tezcan and Turgay $\left(1991,>120 \mathrm{~mW} \mathrm{~m}^{-2}\right.$ for the majority of the region). Based on a comparison of Cenozoic volcanism and heat flow distribution in North America, Blackwell (1978) suggests that heat flow values in excess of $\sim 105 \mathrm{~mW} \mathrm{~m}^{-2}$ in continental regions imply partial melting in the upper crust and related silisic magmatic/volcanic activity. The absence of present-day silisic magmatic/volcanic activity in western Anatolia suggests that regional heat flow values of more than $120 \mathrm{~mW} \mathrm{~m}^{-2}$ are unlikely. On the other hand, some of the moderate heat flow values observed in this study (e.g., the eastern part of Çanakkale) are not observed by Tezcan and Turgay (1991). It is not clear whether these relatively low heat flow areas are due to some near-surface effects, or are representative of a crustal thermal regime. Indeed, equilibrium temperatures from deeper boreholes are needed to make more conclusive statements.

\section{Conclusions}

A total of 113 borehole sites were investigated in western Anatolia, and 55 of them were found to be useful for conductive gradients and/or heat flow analysis. 24 data points fall into class $\mathrm{A} / \mathrm{B} / \mathrm{C}$ quality, and can be used for heat flow mapping. The average heat flow is calculated to be $73 \pm 22 \mathrm{~mW} \mathrm{~m}^{-2}$ in the region. These values are in agreement with the average heat flow of $80 \pm 22 \mathrm{~mW} \mathrm{~m}^{-2}$ measured in the Aegean Sea, as both regions form the back-arc section of the Hellenic subduction zone. The preliminary heat flow map of the region indicates elevated heat flow values (85$95 \mathrm{~mW} \mathrm{~m}^{-2}$ ) in the coastal areas of the study region, including the western part of Çanakkale and the peninsular part of Izmir. The central part of the Menderes Massif is also characterized by elevated heat flow values, the highest values ( $>100 \mathrm{~mW} \mathrm{~m}^{-2}$ ) being near the Kula volcanic center. Moderate heat flow $\left(55-70 \mathrm{~mW} \mathrm{~m}^{-2}\right)$ values are observed in the eastern part of Çanakkale, the central part of Balıkesir, and north of Manisa. Towards the south, moderate heat flow values are also observed in Muğla. With the present data set, it is not clear whether these moderate values represent crustal thermal conditions, or are caused by some near-surface effects.

Due to the shallow depths of the gradient measurements, and uncertainties in the thermal conductivity determinations, results of this study are preliminary. However, heat flow values with their formal errors are reported for the first time in western Anatolia using standard measurement and processing techniques.

Acknowledgements. The author is indebted to M. İlkış1k for providing the field data, which enabled the realization of this study. The author would like to thank S. Ergintav and S. Inan for their support in this research while he was a visiting scholar at Marmara Research Center. This study was supported by the TÜBITTAK BIDEB 2232 program and Marmara University, Scientific Research Commission (FEN-A-100413-0127). Travel support for this project was provided by Marmara University, Scientific Research Commission (FEN-D-130313-0093). The author would also like to thank V. Ediger, B. Erkan, and C. Tapırdamaz (Marmara Research Center) for providing some useful data and software tools. The database of hot springs was obtained from the ATAG Earth Sciences Catalog (coordinator: M. C. Tapirdamaz). The manuscript was greatly improved by constructive reviews of C. Pascal, N. Balling, K. Gessner, M. Ilkışık, M. Richards, Z. Frone, R. Dingwall, and C. Mauroner. Some of the heat flow data processing was performed using the modules of G. R. Beardsmore (http://monash.edu/science/about/schools/geosciences/heatflow/).

Edited by: C. Juhlin

\section{References}

Aktar, M., Karabulut, H., Özalaybey, S., and Childs, D.: A conjugate strike-slip fault system within the extensional tectonics of western Turkey, Geophys. J. Int., 171, 1363-1375, 2007.

Akyol, N., Zhu, L., Mitchell, B. J., Sözbilir, H., and Kekovalı, K.: Crustal structure and local seismicity in western Anatolia, Geophys. J. Int., 166, 1259-1269, 2006.

Balkan, E., Erkan, K., and Şalk, M.: A statistical analysis of thermal conductivities of common rock types in western Turkey, Geothermics, submitted, 2015. 
Beardsmore, G. R. and Cull, C. P.: Crustal heat flow: a guide to measurement and modeling, Cambridge Univ. Press, Cambridge, UK, 2001.

Blackwell, D. D.: Heat flow and energy loss in the Western United States, GSA Memoirs, 152, 175-208, 1978.

Blackwell, D. D.: Heat flow in the northern Basin and Range province, The Role of Heat in the Development of Energy and Mineral Resources in the Northern Basin and Range Province, Geothermal Resources Council, Special Report, 13, 81-93, 1983.

Blackwell, D. D. and Steele, J. L.: Thermal conductivity of sedimentary rocks: measurement and significance, in: Thermal history of sedimentary basins, Springer, New York, 13-36, 1989.

Bonner, J. L., Blackwell, D. D., and Herrin, E. T.: Thermal constraints on earthquake depths in California, B. Seismol. Soc. Am., 93, 2333-2354, 2003.

Bozkurt, E. and Sozbilir, H.: Tectonic evolution of the Gediz Graben: field evidence for an episodic, two-stage extension in western Turkey, Geol. Mag., 141, 63-79, 2004.

Clark, S. P.: Thermal conductivity, in: Handbook of physical constants, edited by: Clark, S., Geol. Soc. Am. Bull. Mem., 90, 587 pp., 1966.

Çiftçi, N. B. and Bozkurt, E.: Structural evolution of the Gediz Graben, SW Turkey: temporal and spatial variation of the graben basin, Basin Res., 22, 846-873, 2010.

Dilek, Y. and Altunkaynak, Ş.: Geochemical and temporal evolution of Cenozoic magmatism in western Turkey: mantle response to collision, slab break-off, and lithospheric tearing in an orogenic belt, Geological Society, London, Special Publications, 311, 213-233, 2009.

Erickson, A., Simmons, J. G., and Ryan, W. B. F.: Review of heat flow data from the Mediterranean and Aegean seas, in: International Symposium on Structural history of the Mediterranean Basins, edited by: Biju-Duval, B. and Montadert, L., Editions Technip, Paris, 263-280, 1977.

Erkan, K. and Blackwell, D. D.: A thermal test of the post-subduction tectonic evolution along the California transform margin, Geophys. Res. Lett., 35, L07309, doi:10.1029/2008GL033479, 2008.

Erkan, K. and Blackwell, D. D.: Transient thermal regimes in the Sierra Nevada and Baja California outer arcs following the cessation of Farallon subduction, J. Geophys. Res., 114, B02107, doi:10.1029/2007JB005498, 2009.

Erkan, K., Holdmann, G., Benoit, W., and Blackwell, D.: Understanding the Chena Hot Springs, Alaska, geothermal system using temperature and pressure data from exploration boreholes, Geothermics, 37, 565-585, 2008.

Fuchs, S., Schütz, F., Förster, H. J., and Förster, A.: Evaluation of common mixing models for calculating bulk thermal conductivity of sedimentary rocks: correction charts and new conversion equations, Geothermics, 47, 40-52, 2013.

Fytikas, M., Innocenti, F., Manetti, P., Peccerillo, A., Mazzuoli, R., and Villari, L.: Tertiary to Quaternary evolution of volcanism in the Aegean region, Geological Society, London, Special Publications, 17, 687-699, 1984.

Gessner, K., Ring, U., Johnson, C., Hetzel, R., Passchier, C. W., and Güngör, T.: An active bivergent rolling-hinge detachment system: Central Menderes metamorphic core complex in western Turkey, Geology, 29, 611-614, 2001.
İlkışık, O. M., Yalçýn, M. N., Sarý, C., Okay, N., Bayrak, M., Öztürk, S., Sener, Ç., Yenigün, H. M., Yemen, H., Sözen, I., and Karamanderesi, I. H.: Ege Bölgesi'nde IsıAkısıAraştırmaları, TÜBITAK Proje No: YDABÇAG-233/G, Ankara, 1996a (in Turkish).

İlkışık, O. M., Sarý, C., Bayrak, M., Öztürk, S., Sener, Ç., Yenigün, H. M., and Karamanderesi, I. H.: Ege Bölgesinde Jeotermik Araştırmalar, TÜBİTAK, Proje No: YDABÇAG-430/G, Ankara, 1996b (in Turkish).

Jaeger, J. C.: Application of the theory of heat conduction to geothermal measurements, in: Terrestrial heat flow, edited by: Lee, H. K., American Geophysical Union, Geophysical Monograph Series, 8, 7-23, 1965.

JICA: The pre-feasibility study on the Dikili-Bergama geothermal development project, Final Report, Japan International Cooperation Agency, Tokyo, MPN 87-160, 1987.

Jolivet, L., Faccenna, C., Huet, B., Labrousse, L., Le Pourhiet, L., Lacombe, O., Lecomte, E., Burov, E., Danele, Y., Brun, J.-P., Philippon, M., Paul, A., Salaün, G., Karabulut, H., Piromallo, C., Monie, P., Gueydan, F., Okay, A. I., Oberhandsli, H., Pourteau, A., Augier, R., Gadenne, L., and Driussi, O.: Aegean tectonics: Strain localisation, slab tearing and trench retreat, Tectonophysics, 597, 1-33, 2013.

Koçyiğit, A., Yusufoğlu, H., and Bozkurt, E.: Evidence from the Gediz Graben for episodic two-stage extension in western Turkey, J. Geol. Soc. London, 156, 605-616, 1999.

Majorowicz, J. and Wybraniec, S.: New terrestrial heat flow map of Europe after regional paleoclimatic correction application, International Journal of Earth Sciences, 100, 881-887, 2011.

Öztürk, S., Karlı, R., and Destur, M.: Türkiye 1s1 haritası projesi raporu: MTA Derleme No 10937, 2006 (in Turkish).

Piromallo, C. and Morelli, A.: P wave tomography of the mantle under the Alpine-Mediterranean area, J. Geophys. Res., 108, 2065, doi:10.1029/2002JB001757, 2003.

Pfister, M., Ryback, L., and Şimşek, Ş.: Geothermal reconnaissance of the Marmara Sea region (NW Turkey): surface heat flow density in an area of active continental extension, Tectonophysics, 291, 77-89, 1998.

Pollack, H. N. and Huang, S.: Climate reconstruction from subsurface temperatures, Annu. Rev. Earth Pl. Sc., 28, 339-365, 2000.

Ring, U., Johnson, C., Hetzel, R., and Gessner, K.: Tectonic denudation of a Late Cretaceous-Tertiary collisional belt: regionally symmetric cooling patterns and their relation to extensional faults in the Anatolide belt of western Turkey, Geol. Mag., 140, 421-441, 2003.

Roy, R. F., Blackwell, D. D., and Decker, E. R.: Continental heat flow, in: The Nature of the Solid Earth, McGraw Hill, New York, 506-543, 1972.

Serpen, Ü., Aksoy, N., Öngür, T., and Korkmaz, E. D.: Geothermal Energy in Turkey: 2008 update, Geothermics, 38, 227-237, 2009.

Seyitoğlu, G. and Scott, B. C.: Age of the Alaşehir graben (west Turkey) and its tectonic implications, Geol. J., 31, 1-11, 1996.

Seyitoglu, G., Işık, V., and Cemen, I.: Complete Tertiary exhumation history of the Menderes Massif, western Turkey: an alternative working hypothesis, Terra Nova, 16, 358-364, 2004.

Tayanç, M., İm, U., Doğruel, M., and Karaca, M.: Climate change in Turkey for the last half century, Climatic Change, 94, 483-502, 2009. 
Tester, J. W., Anderson, B., Batchelor, A., Blackwell, D., DiPippo, R., Drake, E., Garnish, J., Livesay, B., Moore, M. J., Nichols, K., Petty, S., Toksöz, M. N., Veatch Jr., R. W., Baria, R., Augustine C., Enda, M., Negraru, P., and Richards, M.: The Future of Geothermal Energy: Impact of Enhanced Geothermal Systems (EGS) on the United States in the 21st Century, Massachusetts Institute of Technology, 358 pp., 2006.
Tezcan, A. K. and Turgay, M. I.: Heat flow and temperature distribution in Turkey, edited by: Cermak, V., Haenal, R., and Zui, V., Geothermal atlas of Europe, Herman Haack Verlag, Gotha, Germany, 84-85, 1991.

Thakur, M., Blackwell, D. D., and Erkan, K.: The Regional Thermal Regime in Dixie Valley, Nevada, USA, Geothermal Resources Council Trans., 36, 59-67, 2012. 